\title{
Comparing Freshwater Benthic Macroinvertebrate Communities in Forest and Urban Streams of the Coastal Ecological Region of Cameroon
}

\author{
Fils Mamert Onana ${ }^{*}$, Serge Hubert Zebaze Togouet ${ }^{2}$, Antoine Arfao Tamsa ${ }^{3}$, \\ Nectaire Lié Nyamsi Tchatcho ${ }^{1}$, Siméon Tchakonte ${ }^{3}$, Ernest Koji ${ }^{4}$, \\ Armel William Yemtsa Yemeli1, Abigaelle Natacha Sandrine Mouto Makong1
}

${ }^{1}$ Department of Aquatic Ecosystems Management, Institute of Fisheries and Aquatic Sciences, University of Douala, Douala, Cameroon

${ }^{2}$ Department of Animal Biology and Physiology, Faculty of Science, University of Yaoundé I, Yaoundé, Cameroon

${ }^{3}$ Microbiology and Biotechnology Laboratory, Saint Jerome Polytechnic Institute, Saint Jerome Catholic University of Douala, Douala, Cameroon

${ }^{4}$ Department of Animal Biology and Physiology, Faculty of Sciences, University of Douala, Douala, Cameroon

Email: ^filsonana@yahoo.fr

How to cite this paper: Onana, F.M., Zebaze Togouet, S.H., Tamsa, A.A., Nyamsi Tchatcho, N.L., Tchakonte, S., Koji, E., Yemtsa Yemeli, A.W. and Mouto Makong, A.N.S. (2019) Comparing Freshwater Benthic Macroinvertebrate Communities in Forest and Urban Streams of the Coastal Ecological Region of Cameroon. Open Journal of Ecology, 9, 521-537.

https://doi.org/10.4236/oje.2019.912034

Received: November 5, 2019

Accepted: December 24, 2019

Published: December 27, 2019

Copyright $\odot 2019$ by author(s) and Scientific Research Publishing Inc. This work is licensed under the Creative Commons Attribution International License (CC BY 4.0).

http://creativecommons.org/licenses/by/4.0/

\section{cC) (i) Open Access}

\begin{abstract}
In this study conducted in the coastal zone of Cameroon, biological indices and functional feeding groups of benthic macroinvertebrates were used to assess the health status of two urban streams. For a better diagnosis, two streams located in coastal forest zone were used as a reference. Benthic macroinvertebrates were sampled monthly over a 3-month period (from May to July 2017) in six urban stations and six forest stations. Measurements of the physicochemical variables were done simultaneously. Physicochemical analysis revealed that urban streams are strongly polluted with high content of decaying organic matters, while forest streams are slightly polluted as indicated by the Principal Component Analysis. Concerning benthic macroinvertebrates, urban streams are poorly diversified with the proliferation of taxa tolerant to water pollution and belonging to the functional feeding groups of collectorsgatherers. Inversely, forest streams are more diversified and dominated by sensitive taxa, most belonging to the functional feeding groups of predators and shredders. These marked differences between biological indices and feeding mode of benthic macroinvertebrates in forest and urban rivers confirm the reliability of benthic macroinvertebrates as good indicators of freshwater ecosystem in the coastal zone of Cameroon.
\end{abstract}




\section{Keywords}

Urban and Forest Streams, Benthic Macroinvertebrates, Water Pollution, Biological Indices, Functional Feeding Groups

\section{Introduction}

Assessment of the impacts of urbanization on rivers and streams involves the research and use of a wide range of physical, chemical, and biological indicators [1]. However, [2] recommend the use of biological communities at the expense of physicochemical variables which provide a punctual approximation of the quality of the environment. The benthic macroinvertebrates are metazoans that are widely represented in rivers and streams and constitute a good tool for this diagnosis [3]. Their preference for biological monitoring of rivers is justified for to the following characteristics [2]: 1) they occupy a wide range of trophic levels and pollution tolerance, providing solid information for the interpretation of cumulative effects due to exposure to pollutants; 2) their sedentary life style make it possible to reflect the local conditions of the environment, and to give a significant image of the quality of the habitat over time.

In Cameroon, the use of benthic macroinvertebrates as bioindicators of the health status of rivers has expanded considerably in the last 15 years. However, most of the works on this group of organisms has been conducted in urban and forest streams in the South-Central Forest Ecological region with bimodal rainfall [4] [5] [6]. The data available for the coastal eco-zone with unimodal rainfall relate to only a few urban and peri-urban rivers in the industrial-port city of Douala [7] [8] [9]. To date and to our knowledge, no study has been conducted on the ecology of benthic macroinvertebrates of coastal forest streams in the unimodal rainfall ecological region. However, in order to understand the functioning of a biological system, it must be understood and interpreted according to its particular ecological situation and implicitly implies a reference model adapted to the ecological region considered [10].

The main objective of this study is to assess the impact of urban pollution during the rainy season on the diversity of benthic macroinvertebrates communities of two streams of the industrial-port city of Douala, as compared to the referential status of two other streams chosen in a natural forested river basin at Yabassi. The specific objectives of this study are: 1) to evaluate the physicochemical quality of the waters of the forest and urban streams; 2) to determine the variation in the structure of benthic macroinvertebrates communities of naturally vegetated watersheds and urban watersheds using the biological indices and functional feeding groups; 3 ) to determine the main physicochemical variables that influence the distribution and the dynamic of benthic macroinvertebrates in the studied streams. 


\section{Materials and Methods}

\subsection{Study Area and Sampling Stations}

The present study was conducted in the littoral region of Cameroon, which is subject to a unimodal equatorial climate of Guinean type and Cameroonian coastal sub-type, characterized by two seasons: a long rainy season of 9 months (March-November) and a shot dry season of 3 months (December to February) [11]. Rainfalls are abundant and regular y $(2596$ - $5328 \mathrm{~mm})$. The air temperature is relatively high with a monthly average of $28^{\circ} \mathrm{C}$. The streams chosen for study are situated in the localities of Douala and Yabassi. Table 1 presents the characteristics of sampling stations.

The locality of Yabassi extends on a surface area of approximately $3080 \mathrm{~km}^{2}$ located between $4^{\circ} 27^{\prime}$ and $4^{\circ} 40^{\prime}$ of latitude North and between $9^{\circ} 57^{\prime}$ and $10^{\circ} 10^{\prime}$ of longitude East. It has a population of about 14,685, representing a density of 4.77 inhabitants per $\mathrm{km}^{2}$. Watersheds are covered more than $85 \%$ by of a dense evergreen forest composed of big trees with an important canopy. In Yabassi, two streams namely Makono and Ndima were chosen for the study (Figure 1(a)). Three sampling stations coded Mak1, Mak2 and Mak3 were positioned respectively in the upper, middle and lower sections of the Makono stream. In the Ndima stream, three sampling stations were also chosen (Ndi1, Ndi2 and $\mathrm{Ndi3}$ ) and located respectively in the upper, middle and lower sections of the stream (Figure 1(a)).

The city of Douala lies between $3^{\circ} 58^{\prime}$ and $4^{\circ} 7^{\prime}$ of latitude North and between $9^{\circ} 34^{\prime}$ and $9^{\circ} 49^{\prime}$ of longitude East. It covers a surface area of approximately 923 $\mathrm{km}^{2}$ for an estimated population of about 2.8 million inhabitants, with a density of 3033.59 inhabitants per $\mathrm{km}^{2}$. For this study, two streams were selected (Mboppi and Simbi) (Figure 1(b)). The Mboppi river basin is characterized by

Table 1. Characteristics of the study sites.

\begin{tabular}{|c|c|c|c|c|c|c|c|c|}
\hline Stream & $\begin{array}{l}\text { Sampling } \\
\text { station }\end{array}$ & Latitude N & Longitude E & $\begin{array}{l}\text { Altitude } \\
\text { (m) }\end{array}$ & $\begin{array}{c}\text { Stream width } \\
\text { (m) }\end{array}$ & $\begin{array}{c}\text { Stream } \\
\text { depth }(\mathrm{cm})\end{array}$ & $\begin{array}{c}\text { Current } \\
\text { velocity }(\mathrm{m} / \mathrm{s})\end{array}$ & $\begin{array}{l}\text { Dominant } \\
\text { Substrate }\end{array}$ \\
\hline \multirow{3}{*}{ Makono } & Mak1 & $04^{\circ} 25^{\prime} 32.43^{\prime \prime}$ & $10^{\circ} 0^{\prime} 19.37^{\prime \prime}$ & 69 & 1.50 & 20.20 & 0.52 & Sand, gravel \\
\hline & Mak2 & $04^{\circ} 25^{\prime} 3.36^{\prime \prime}$ & $09^{\circ} 59^{\prime} 0.74^{\prime \prime}$ & 38 & 2 & 75.30 & 0.38 & Mud, Sand \\
\hline & Mak3 & $04^{\circ} 25^{\prime} 35.27^{\prime \prime}$ & $09^{\circ} 57^{\prime} 32.50^{\prime \prime}$ & 24 & 2.50 & 45.80 & 0.24 & Sand, gravel \\
\hline \multirow{3}{*}{ Ndima } & Ndil & $04^{\circ} 27^{\prime} 9.20^{\prime \prime}$ & $10^{\circ} 0^{\prime} 42.85^{\prime \prime}$ & 70 & 1.80 & 8.70 & 0.61 & Sand, gravel \\
\hline & Ndi2 & $04^{\circ} 26^{\prime} 32.31^{\prime \prime}$ & $09^{\circ} 59^{\prime} 20.43^{\prime \prime}$ & 36 & 4.20 & 25.10 & 0.39 & Sand, gravel \\
\hline & Ndi3 & $04^{\circ} 26^{\prime} 8.97^{\prime \prime}$ & $09^{\circ} 58^{\prime} 03.76^{\prime \prime}$ & 34 & 7.40 & 30.50 & 0.21 & Sand \\
\hline \multirow{3}{*}{ Mboppi } & M1 & $04^{\circ} 02^{\prime} 70^{\prime \prime}$ & $09^{\circ} 42^{\prime} 23.17^{\prime \prime}$ & 11 & 1.60 & 23 & 0.28 & Sand \\
\hline & M2 & $04^{\circ} 03^{\prime} 0.71^{\prime \prime}$ & $09^{\circ} 42^{\prime} 28.53^{\prime \prime}$ & 6 & 2.80 & 50.60 & 0.14 & Mud \\
\hline & M3 & $04^{\circ} 03^{\prime} 39.72^{\prime \prime}$ & $09^{\circ} 42^{\prime} 17.67^{\prime \prime}$ & 2 & 3.60 & 30.40 & 0.15 & Mud \\
\hline \multirow{3}{*}{ Simbi } & S1 & $04^{\circ} 02^{\prime} 6.97^{\prime \prime}$ & $09^{\circ} 44^{\prime} 38.16^{\prime \prime}$ & 16 & 1.90 & 24.70 & 0.30 & Sand \\
\hline & S2 & $04^{\circ} 01^{\prime} 48.48^{\prime \prime}$ & $09^{\circ} 44^{\prime} 20.10^{\prime \prime}$ & 14 & 2.80 & 36.30 & 0.17 & Mud, sand \\
\hline & S3 & $04^{\circ} 01^{\prime} 5.02^{\prime \prime}$ & $09^{\circ} 44^{\prime} 14.28^{\prime \prime}$ & 7 & 4.10 & 20.70 & 0.15 & Mud, Sand \\
\hline
\end{tabular}



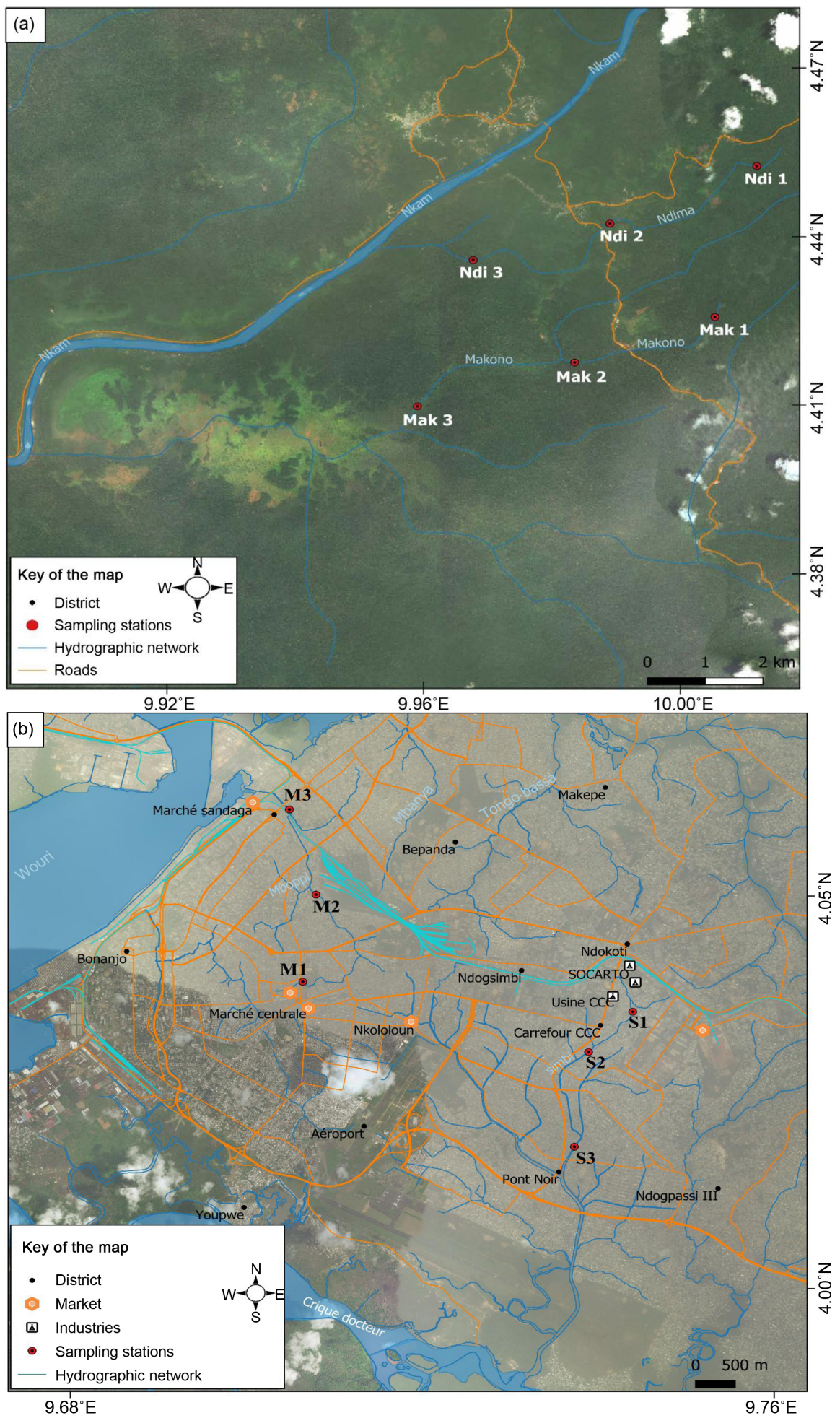

Figure 1. Hydrographic map of the study area showing sampling stations. Yabassi (a); Douala (b).

the presence of the biggest markets of the city of Douala (Congo market, Mboppi market, Nkololoun market, Central market, Sandaga market). Three sampling stations were positioned on the Mboppi stream: M1, M2 and M3 located respec- 
tively in the upper, middle and lower sections of the stream (Figure 1(b)). The Simbi watershed is characterized by the presence of some industries whose effluent flows into the Simbi stream: Cameroonian Chemical Complex (CCC), paper making industry (SOCARTO) and industries specialized in the Modeling of Synthetic Organic Products (SCIMPOS). Three sampling stations were positioned on the Simbi stream. Station S1 is located in the upstream, S2 is situated in the middle section of the stream and S3 positioned downstream.

\subsection{Physicochemical Analyzes}

The measurements of the physicochemical parameters at each of the twelve sampling stations were done monthly, between 7 and $10 \mathrm{am}$, from May to July 2017. These measurements were conducted in accordance with standard methods described by [12]. Thus, a total of 36 measurements were carried out for each parameter (18 measurements in the 6 stations of the forest streams and 18 others in the 6 stations of the urban streams). Water temperature (T), $\mathrm{pH}$, electrical conductivity (EC), and dissolved oxygen concentration (DO) were measured in situ using a portable multi-parameter HANNA HI 9829. For the parameters intended to be measured in the laboratory, samples of water were collected at each sampling point using pre-clean double-capped polyethylene bottle of $500 \mathrm{ml}$, and preserved in refrigerated conditions. Turbidity (Turb), water color (Col), Suspended Solids (SS), Orthophosphate $\left(\mathrm{PO}_{4}^{3-}\right)$, Ammonium $\left(\mathrm{NH}_{4}^{+}\right)$and Nitrites $\left(\mathrm{NO}_{2}^{-}\right)$were measured using a $\mathrm{HACH} \mathrm{DR/3900} \mathrm{spectrophotometer.} \mathrm{To} \mathrm{as-}$ sess the organic pollution level, the Organic Pollution Index (OPI) was calculated according to the methodology described by [13] which is based on three ion concentrations $\left(\mathrm{NH}_{4}^{+}, \mathrm{NO}_{2}^{-}\right.$and $\left.\mathrm{PO}_{4}^{3-}\right)$. For each parameter, 5 classes of contents having an ecological significance are defined (Table 2). The OPI corresponds to the arithmetic mean value of the class number of each parameter and the values obtained are apportioned into 5 levels of pollution (Table 3).

Table 2. Boundary of the Organic Pollution Index (OPI) classes.

\begin{tabular}{|c|c|c|c|}
\hline \multicolumn{4}{|c|}{ Parameters } \\
\hline Classes & $\mathrm{NH}_{4}^{+} \quad(\mathrm{mg}-\mathrm{N} / \mathrm{l})$ & $\mathrm{NO}_{2}^{-} \quad(\mu \mathrm{g}-\mathrm{N} / \mathrm{l})$ & $\mathrm{PO}_{4}^{3-} \quad(\mu \mathrm{g}-\mathrm{N} / \mathrm{l})$ \\
\hline 5 & $<0.10$ & 5 & 15 \\
\hline 4 & $0.10-0.90$ & $6-10$ & $16-75$ \\
\hline 3 & $1-2.40$ & $11-50$ & $76-250$ \\
\hline 2 & $2.50-6$ & $51-150$ & $251-900$ \\
\hline 1 & $>6$ & $>150$ & $>900$ \\
\hline
\end{tabular}

Table 3. Classification of the pollution level according to the class values of the OPI.

\begin{tabular}{cccccc}
\hline OPI Class & $1.00-1.90$ & $2.00-2.90$ & $3.00-3.90$ & $4.00-4.50$ & $4.60-5.00$ \\
$\begin{array}{c}\text { Organic pollution } \\
\text { level }\end{array}$ & Very high & High & Moderate & Low & Null \\
\hline
\end{tabular}




\subsection{Sampling and Identification of Benthic Macroinvertebrates}

Benthic macroinvertebrates samples were collected at each station using a longhandled kick net $(30 \mathrm{~cm} \times 30 \mathrm{~cm}$ side, $400-\mu \mathrm{m}$ mesh size and $45 \mathrm{~cm}$ of depth). All the available habitats within the study station including leaf packs, branches, macrophyte beds, sand, mud and rafts were sampled. Samplings were done in a 100-m stretch for each station, following protocols described by [14]. At each sampling station, 20 drags of the kick net were done in different micro-habitats, each corresponding to a surface area of $0.3 \mathrm{~m}^{2}(30 \mathrm{~cm} \times 100 \mathrm{~cm})$, for a total sampled surface area of $6 \mathrm{~m}^{2}$ per station. Each time, the benthic macroinvertebrates retained by the meshes of the net were sorted and collected using a pair of fine forceps, and then introduced into plastic bottles containing $70 \%$ alcohol. In the laboratory, all of the benthic macroinvertebrates at each sampling station were identified to the family taxonomic level and counted, using a Wild M5 stereomicroscope and appropriate taxonomic identification keys proposed by [15] [16] [17]. Recent research indicates that extensive identification up to the family provides a sufficient level of taxonomic resolution to detect responses of the communities studied to anthropogenic disturbances [18].

\subsection{Benthic Macroinvertebrates Metrics and Indices}

The diversity index of Shannon and Weaver $\left(\mathrm{H}^{\prime}\right)$ and the Pielou's evenness index (J) were calculated from the taxonomic richness (S) and abundance (TA) of macroinvertebrates. These indices informed on the distribution of individuals within the taxa so as to compare the diversity of the communities of the different sampling stations [19]. The assumption is that undisturbed environments are characterized by high diversity or richness and an even distribution of individuals among the Taxa [20].

Seven benthic macroinvertebrate's metrics were calculated to analyze the community structure: taxonomic richness of the groups Ephemeroptera-Plecoptera-Trichoptera (S-EPT), Plecoptera-Odonata Ephemeroptera-Trichoptera (SPOET), relative abundance of the group EPT (\%-EPT), relative abundance of Insecta (\%-Ins), relative abundance of Diptera (\%-Dip), relative abundance of Insecta Non Diptera (\%-Ins-N-Dip), and relative abundance of Oligochaeta (\%-Oligo). Significant changes in the value of these metrics can indicate environmental disturbances, including freshwater pollution and habitat degradation [18].

The adaptation of benthic macroinvertebrates to organic pollution was assessed through six metrics: relative abundance of taxa tolerant to pollution (\%-To; tolerance score $>6$ ), relative abundance of taxa sensitive to pollution (\%-Into; tolerance score $<4$ ), relative abundance of dominant taxon (\%-Dom), Hilsenhoff index (FBI), Biological Monitoring Working Party (BMWP) and Average Score Per Taxon (ASPT). Indeed, the sensitivity and tolerance of indicator assemblages to a number of environmental characteristics, such as organic pollution, heavy metals, pesticides and eutrophication are known to differ among 
taxa [21]. The tolerance score assigned to each organism in this study was taken from [22] [23].

Lastly, we assigned each taxon to one of the five functional feeding groups (FFGs): shredders (shr), scrapers (scr), collectors-gatherers (c-g), collectors-filterers (c-f) and predators (prd); based on the food habit descriptions in literature [16]-[24]. In fact, functional approach which the goal is to characterize ecosystem condition uses FFGs to describe ecosystem attributes in streams [24].

\subsection{Statistical Analyses}

A Principal Component Analysis (PCA) was performed on the physicochemical data set made up of 10 variables measured on the 36 water samples collected during the study. This PCA permitted us to identify firstly homogeneous groups having great physicochemical characteristic similarities, and secondly, characterizing each group according to the physicochemical variables measured. The purpose of this test was to discriminate samples from forest and urban sites according to pollution gradient. The normality test of Shapiro Wilk was carried out before comparing the biotic and abiotic parameters of forests and urban streams. In addition, the Man Whitney U-test was performed to search for significant differences between the physicochemical variables measured at forest and urban sites, and also between the benthic macroinvertebrates metrics values of these two groups of samples. Relationships between physicochemical variables and metrics obtained from benthic macroinvertebrates were determined using Spearman's correlation test and PCA. All the statistical analyses were compiled using the XLSTAT 2007 software.

\section{Results}

\subsection{Physicochemical Quality of Water}

Except for orthophosphates, the values of $\mathrm{pH}$, temperature, electrical conductivity, color, Suspended Solids, turbidity, ammonia and nitrite were significantly lower $(\mathrm{P}<0.01)$ at the forest stations compared those recorded in the urban stations. Inversely, the highest values of dissolved oxygen were recorded at the forest stations, while the urban stations showed very high oxygen content (Table 4). Moreover, the organic pollution level of the water was moderate at the forest sites (OPI $=3.41 \pm 0.54)$ whereas in the urban area it was high (OPI $=2.11 \pm$ 0.58) (Table 4).

The PCA carried out with the physicochemical parameters data set shows that the first two axes F1 (58.36\%) and F2 (18.21\%) accounted for 76.57\% of the total variance (Figure 2). The distribution of the 36 water samples on factorial plane of the PCA allowed to discriminate the sampling sites into two groups (Figure 2(b)): Group A, consisting of all the samples collected from the Makono and Ndima streams which are located in a forested zone (Yabassi) and which are characterized by good oxygenation of water and low concentrations of organic matter (high OPI) (Figure 2(a)). Group B, regrouping the samples collected 
Table 4. Mean and standard deviation (SD) values of the physicochemical variables at each sampling station of forest and urban streams.

\begin{tabular}{|c|c|c|c|c|c|c|c|c|c|c|c|c|c|c|}
\hline \multirow[b]{2}{*}{$\begin{array}{l}\text { Parame } \\
\text { ters }\end{array}$} & \multicolumn{7}{|c|}{ Forest streams } & \multicolumn{7}{|c|}{ Urban streams } \\
\hline & $\begin{array}{c}\text { Mak1 } \\
(\mathrm{n}=3)\end{array}$ & $\begin{array}{c}\text { Mak2 } \\
(n=3)\end{array}$ & $\begin{array}{c}\text { Mak3 } \\
(n=3)\end{array}$ & $\begin{array}{c}\text { Ndil } \\
(\mathrm{n}=3)\end{array}$ & $\begin{array}{c}\text { Ndi2 } \\
(\mathrm{n}=3)\end{array}$ & $\begin{array}{l}\text { Ndi3 } \\
(n=3)\end{array}$ & $\begin{array}{c}\text { Means } \pm \\
\text { SD } \\
(n=18)\end{array}$ & $\begin{array}{c}\text { M1 } \\
(n=3)\end{array}$ & $\begin{array}{c}\text { M2 } \\
(n=3)\end{array}$ & $\begin{array}{c}\text { M3 } \\
(n=3)\end{array}$ & $\begin{array}{c}S 1 \\
(n=3)\end{array}$ & $\begin{array}{c}S 2 \\
(n=3)\end{array}$ & $\begin{array}{c}\text { S3 } \\
(n=3)\end{array}$ & $\begin{array}{c}\text { Means } \pm \\
\text { SD } \\
(n=18)\end{array}$ \\
\hline $\mathrm{T}\left({ }^{\circ} \mathrm{C}\right)$ & $\begin{array}{c}21.27 \pm \\
1.10\end{array}$ & $\begin{array}{c}19.17 \pm \\
0.76\end{array}$ & $\begin{array}{c}18.33 \pm \\
0.58\end{array}$ & $20 \pm 10$ & $\begin{array}{c}20.43 \pm \\
0.51\end{array}$ & $\begin{array}{c}19.73 \pm \\
1.57\end{array}$ & $\begin{array}{c}19.82 \pm \\
1.26^{\mathrm{a}}\end{array}$ & $\begin{array}{c}26.33 \pm \\
1.76\end{array}$ & $\begin{array}{c}26.43 \pm \\
1.29\end{array}$ & $\begin{array}{c}26.57 \pm \\
1.40\end{array}$ & $26 \pm 1.00$ & $\begin{array}{c}26.27 \pm \\
1.61\end{array}$ & $\begin{array}{c}26.17 \pm \\
2.02\end{array}$ & $\begin{array}{c}26.29 \pm \\
1.32^{\mathrm{b}}\end{array}$ \\
\hline $\mathrm{pH}$ & $\begin{array}{c}5.85 \pm \\
0.14\end{array}$ & $\begin{array}{c}6.68 \pm \\
0.03\end{array}$ & $\begin{array}{c}6.83 \pm \\
0.02\end{array}$ & $\begin{array}{c}6.91 \pm \\
0.45\end{array}$ & $\begin{array}{c}7.06 \pm \\
0.59\end{array}$ & $\begin{array}{c}7.21 \pm \\
0.36\end{array}$ & $\begin{array}{c}6.76 \pm \\
0.53^{\mathrm{a}}\end{array}$ & $\begin{array}{c}7.25 \pm \\
0.12\end{array}$ & $\begin{array}{c}7.18 \pm \\
0.14\end{array}$ & $\begin{array}{c}7.21 \pm \\
0.16\end{array}$ & $\begin{array}{c}6.93 \pm \\
0.10\end{array}$ & $\begin{array}{c}7.79 \pm \\
1.49\end{array}$ & $\begin{array}{c}7.03 \pm \\
0.27\end{array}$ & $\begin{array}{c}7.23 \pm \\
0.60^{\mathrm{b}}\end{array}$ \\
\hline DO (\%) & $\begin{array}{c}37.03 \pm \\
4.57\end{array}$ & $\begin{array}{c}41.50 \pm \\
9.56\end{array}$ & $\begin{array}{c}38.70 \pm \\
5.66\end{array}$ & $\begin{array}{c}64.97 \pm \\
1.25\end{array}$ & $\begin{array}{c}63.73 \pm \\
2.24\end{array}$ & $\begin{array}{c}62.53 \pm \\
2.41\end{array}$ & $\begin{array}{c}51.41 \pm \\
13.48^{\mathrm{a}}\end{array}$ & $\begin{array}{c}26.03 \pm \\
5.35\end{array}$ & $\begin{array}{c}30.4 \pm \\
1.65\end{array}$ & $\begin{array}{c}32.5 \pm \\
0.17\end{array}$ & $\begin{array}{c}29.07 \pm \\
2.34\end{array}$ & $\begin{array}{c}29.73 \pm \\
4.47\end{array}$ & $\begin{array}{c}28.07 \pm \\
10.47\end{array}$ & $\begin{array}{c}29.30 \pm \\
4.88^{\mathrm{b}}\end{array}$ \\
\hline $\begin{array}{c}\mathrm{EC} \\
(\mu \mathrm{S} / \mathrm{cm})\end{array}$ & $\begin{array}{c}35.33 \pm \\
2.31\end{array}$ & $\begin{array}{c}36.67 \pm \\
2.52\end{array}$ & $\begin{array}{c}34.67 \pm \\
4.16\end{array}$ & $\begin{array}{c}21.30 \pm \\
5.89\end{array}$ & $\begin{array}{c}23.07 \pm \\
1.27\end{array}$ & $\begin{array}{c}24.27 \pm \\
2.68\end{array}$ & $\begin{array}{c}29.22 \pm \\
7.23^{\mathrm{a}}\end{array}$ & $\begin{array}{c}799.67 \pm \\
770.70\end{array}$ & $\begin{array}{c}701.67 \pm \\
620.77\end{array}$ & $\begin{array}{c}732.9 \pm \\
695.96\end{array}$ & $\begin{array}{c}383.43 \pm \\
387.62\end{array}$ & $\begin{array}{c}2345.67 \pm \\
3693.20\end{array}$ & $\begin{array}{c}1172.13 \pm \\
1502.17\end{array}$ & $\begin{array}{c}1022.58 \pm \\
1577.46^{\mathrm{b}}\end{array}$ \\
\hline $\begin{array}{c}\text { Col } \\
\text { (Pt.Co) }\end{array}$ & $\begin{array}{c}8.67 \pm \\
3.51\end{array}$ & $\begin{array}{l}27 \pm \\
6.56\end{array}$ & $\begin{array}{c}33.33 \pm \\
12.50\end{array}$ & $\begin{array}{l}15 \pm \\
5.00\end{array}$ & $\begin{array}{c}31.67 \pm \\
30.55\end{array}$ & $\begin{array}{c}26 \pm \\
20.07\end{array}$ & $\begin{array}{c}23.61 \pm \\
16.39^{\mathrm{a}}\end{array}$ & $\begin{array}{c}610.67 \pm \\
205.18\end{array}$ & $\begin{array}{c}549.33 \pm \\
153.66\end{array}$ & $\begin{array}{c}366 \pm \\
129.98\end{array}$ & $\begin{array}{c}129.67 \pm \\
30.09\end{array}$ & $\begin{array}{c}794.67 \pm \\
791.62\end{array}$ & $\begin{array}{c}555 \pm \\
428.77\end{array}$ & $\begin{array}{c}500.89 \pm \\
388.64^{\mathrm{b}}\end{array}$ \\
\hline $\begin{array}{c}\text { SS } \\
(\mathrm{mg} / \mathrm{l})\end{array}$ & $\begin{array}{c}0.33 \pm \\
0.58\end{array}$ & $\begin{array}{c}2.33 \pm \\
3.21\end{array}$ & $\begin{array}{c}6 \pm \\
50.29\end{array}$ & $\begin{array}{c}2.67 \pm \\
2.08\end{array}$ & $\begin{array}{l}14 \pm \\
9.16\end{array}$ & $9 \pm 7.21$ & $\begin{array}{c}5.72 \pm \\
6.62^{\mathrm{a}}\end{array}$ & $\begin{array}{l}99 \pm \\
19.16\end{array}$ & $\begin{array}{c}80.67 \pm \\
28.38\end{array}$ & $\begin{array}{c}55.33 \pm \\
38.73\end{array}$ & $13 \pm 4.58$ & $\begin{array}{c}77.67 \pm \\
71.51\end{array}$ & $\begin{array}{c}80 \pm \\
53.03\end{array}$ & $\begin{array}{c}67.61 \pm \\
45.29^{\mathrm{b}}\end{array}$ \\
\hline $\begin{array}{l}\text { Turb } \\
\text { (NTU) }\end{array}$ & $\begin{array}{c}8.25 \pm \\
3.38\end{array}$ & $\begin{array}{c}9.86 \pm \\
16.84\end{array}$ & $\begin{array}{c}11.73 \pm \\
20.32\end{array}$ & $\begin{array}{c}1.33 \pm \\
1.15\end{array}$ & $\begin{array}{c}1.33 \pm \\
1.15\end{array}$ & $\begin{array}{c}2.33 \pm \\
1.53\end{array}$ & $\begin{array}{l}5.81 \pm \\
10.16^{\mathrm{a}}\end{array}$ & $\begin{array}{c}82 \pm \\
26.91\end{array}$ & $\begin{array}{l}101 \pm \\
20.07\end{array}$ & $\begin{array}{c}61 \pm \\
25.36\end{array}$ & $\begin{array}{c}24.33 \pm \\
9.07\end{array}$ & $\begin{array}{c}138.33 \pm \\
147.01\end{array}$ & $\begin{array}{c}90.33 \pm \\
90.17\end{array}$ & $\begin{array}{c}82.83 \pm \\
70.83^{b}\end{array}$ \\
\hline $\begin{array}{l}\mathrm{NH}_{4}^{+} \\
(\mathrm{mg} / \mathrm{l})\end{array}$ & $\begin{array}{c}0.53 \pm \\
0.58\end{array}$ & $\begin{array}{c}0.75 \pm \\
0.82\end{array}$ & $\begin{array}{c}0.9 \pm \\
0.69\end{array}$ & $\begin{array}{c}0.07 \pm \\
0.01\end{array}$ & $\begin{array}{c}0.13 \pm \\
0.14\end{array}$ & $\begin{array}{c}0.56 \pm \\
0.32\end{array}$ & $\begin{array}{c}0.49 \pm \\
0.54^{\mathrm{a}}\end{array}$ & $\begin{array}{c}5.85 \pm \\
4.33\end{array}$ & $\begin{array}{c}11.51 \pm \\
9.25\end{array}$ & $\begin{array}{c}6.42 \pm \\
5.45\end{array}$ & $\begin{array}{c}1.65 \pm \\
1.45\end{array}$ & $\begin{array}{c}1.96 \pm \\
1.29\end{array}$ & $\begin{array}{c}3.43 \pm \\
2.38\end{array}$ & $\begin{array}{c}5.14 \pm \\
5.37^{\mathrm{b}}\end{array}$ \\
\hline $\begin{array}{c}\mathrm{NO}_{2}^{-} \\
(\mathrm{mg} / \mathrm{l})\end{array}$ & $\begin{array}{c}0.01 \pm \\
0.001\end{array}$ & $\begin{array}{c}0.003 \pm \\
0.003\end{array}$ & $\begin{array}{c}0.01 \pm \\
0.01\end{array}$ & $\begin{array}{c}0.01 \pm \\
0.01\end{array}$ & $\begin{array}{c}0.01 \pm \\
0.02\end{array}$ & $\begin{array}{c}0.04 \pm \\
0.03\end{array}$ & $\begin{array}{c}0.01 \pm \\
0.02^{\mathrm{a}}\end{array}$ & $\begin{array}{c}0.06 \pm \\
0.02\end{array}$ & $\begin{array}{c}0.04 \pm \\
0.00\end{array}$ & $\begin{array}{c}0.03 \pm \\
0.01\end{array}$ & $\begin{array}{c}0.32 \pm \\
0.33\end{array}$ & $\begin{array}{c}0.65 \pm \\
1.07\end{array}$ & $\begin{array}{c}0.07 \pm \\
0.04\end{array}$ & $\begin{array}{c}0.20 \pm \\
0.45^{\mathrm{b}}\end{array}$ \\
\hline $\begin{array}{c}\mathrm{PO}_{4}^{3-} \\
(\mathrm{mg} / \mathrm{l})\end{array}$ & $\begin{array}{c}0.70 \pm \\
0.81\end{array}$ & $\begin{array}{c}0.57 \pm \\
0.82\end{array}$ & $\begin{array}{c}0.32 \pm \\
0.28\end{array}$ & $\begin{array}{c}1.16 \pm \\
0.93\end{array}$ & $\begin{array}{c}1.17 \pm \\
0.60\end{array}$ & $\begin{array}{c}0.82 \pm \\
0.66\end{array}$ & $\begin{array}{c}0.79 \pm \\
0.68^{\mathrm{a}}\end{array}$ & $\begin{array}{c}2.50 \pm \\
1.13\end{array}$ & $\begin{array}{c}3.50 \pm \\
2.12\end{array}$ & $\begin{array}{c}1.08 \pm \\
0.95\end{array}$ & $\begin{array}{c}0.82 \pm \\
0.59\end{array}$ & $\begin{array}{c}0.69 \pm \\
1.01\end{array}$ & $\begin{array}{c}1.30 \pm \\
0.78\end{array}$ & $\begin{array}{c}1.65 \pm \\
1.45^{\mathrm{a}}\end{array}$ \\
\hline IPO & $\begin{array}{c}3.22 \pm \\
0.77\end{array}$ & $\begin{array}{c}3.78 \pm \\
0.51\end{array}$ & $\begin{array}{c}3.67 \pm \\
0.34\end{array}$ & $\begin{array}{c}3.56 \pm \\
0.20\end{array}$ & $\begin{array}{c}3.22 \pm \\
0.19\end{array}$ & $\begin{array}{c}3 \pm \\
0.88\end{array}$ & $\begin{array}{c}3.41 \pm \\
0.54^{\mathrm{a}}\end{array}$ & $\begin{array}{c}1.56 \pm \\
0.19\end{array}$ & $\begin{array}{c}1.78 \pm \\
0.19\end{array}$ & $\begin{array}{c}2.33 \pm \\
0.58\end{array}$ & $\begin{array}{c}2.11 \pm \\
0.69\end{array}$ & $\begin{array}{c}2.78 \pm \\
0.69\end{array}$ & $\begin{array}{c}2.11 \pm \\
0.38\end{array}$ & $\begin{array}{c}2.11 \pm \\
0.58^{\mathrm{b}}\end{array}$ \\
\hline
\end{tabular}

Mann Whitney tests were used to evaluate differences among the two groups of streams (forest streams and urban streams). The values followed by the superscript $(a, b)$ for a given physicochemical parameter indicate that this parameter is significantly different between forest and urban streams $(\mathrm{P}<0.01)$.

from the Simbi and Mboppi streams, located in Douala. These urban sampling sites have very poor water quality with higher values of water color, turbid, ions content, and important organic matter load.

\subsection{Benthic Macroinvertebrates Communities' Structure}

Considering spatial distribution of the taxonomic richness, 36 families divided into 4 classes (Crustacea Gastropoda, Insecta, Oligochaeta) and 12 orders were collected in the forest sites, while in the urban area, only 16 families belonging to 4 classes (Achaeta, Oligochaeta, Gastropoda, Insecta) and 7 orders were identified. In the forest streams, the most represented orders are Ephemeroptera and Odonata, with 6 families each. They are followed by the Hemiptera and Coleoptera with 5 families each. Moreover, Plecoptera of the family Perlidae and Trichoptera of the family Hydropsychidae are present in the two forest streams. In urban streams, Ephemeroptera, Plecoptera, Trichoptera and Odonata are absent 

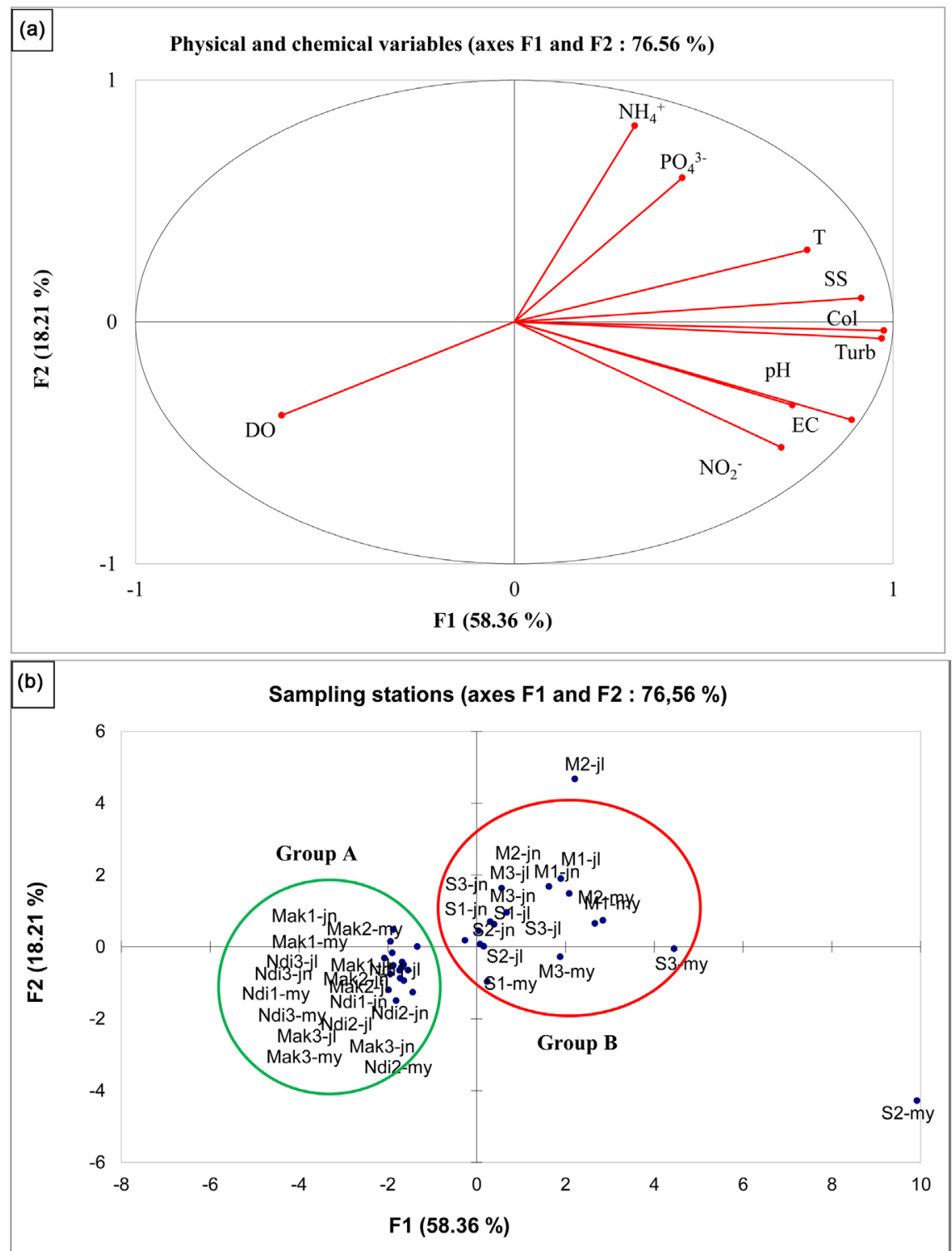

Figure 2. Projections of the physicochemical variables of water samples collected on the plane of the first two axes of the PCA. Correlation circle (a) and grouping of stations into two classes based on their physicochemical characteristics (b); where my, jn et jl represent respectively sampling months May, June and July.

while Diptera, Haplotaxida and Basommatophora are the most represented orders with 5, 4 and 4 families respectively. Similarly, Decapoda crustaceans are absent in urban streams while in forest streams, they were present and represented by 4 families. In addition, the average number of family (S), the S-EPT and S-POET metric values were significantly higher $(\mathrm{P}<0.01)$ in forest stream than those recorded in urban stations (Table 5).

As regards the abundances, the Mboppi and Simbi urban streams despite their low taxonomic richness (16 families), have the highest abundance with 750 individuals. This could be due to the proliferation of pollution-resistant taxa such as Physidae (48.80\%), Lymnaeidae (20.53\%) and Chironomidae (13.20\%), which 
Table 5. Values of the metrics used to describe the benthic macroinvertebrates communities' structure and to measure the pollution tolerance.

\begin{tabular}{|c|c|c|c|c|c|c|c|c|c|c|c|c|c|c|}
\hline \multirow[b]{2}{*}{ Metrics } & \multicolumn{7}{|c|}{ Forest rivers } & \multicolumn{7}{|c|}{ Urban rivers } \\
\hline & Mak1 & Mak2 & Mak3 & Ndi1 & Ndi2 & Ndi3 & $\begin{array}{c}\text { Means } \pm S D \\
(n=6)\end{array}$ & M1 & M2 & M3 & S1 & S2 & S3 & $\begin{array}{c}\text { Means } \pm S D \\
\quad(n=6)\end{array}$ \\
\hline \multicolumn{15}{|c|}{ Community structure } \\
\hline \multicolumn{15}{|c|}{ Index } \\
\hline$S$ & 16 & 13 & 9 & 15 & 16 & 17 & $14.33 \pm 2.94^{\mathrm{a}}$ & 7 & 10 & 6 & 8 & 7 & 11 & $8.17 \pm 1.94^{\mathrm{b}}$ \\
\hline TA & 125 & 139 & 104 & 73 & 83 & 101 & $\begin{array}{c}104.16 \pm \\
724.81^{\mathrm{a}}\end{array}$ & 62 & 252 & 23 & 255 & 86 & 72 & $125 \pm 101.72^{\mathrm{a}}$ \\
\hline S-EPT & 1 & 4 & 2 & 1 & 4 & 1 & $2.17 \pm 1.47^{\mathrm{a}}$ & 0 & 0 & 0 & 0 & 0 & 0 & $0^{\mathrm{b}}$ \\
\hline S-POET & 5 & 5 & 3 & 5 & 7 & 6 & $5.17 \pm 1.33^{\mathrm{a}}$ & 0 & 0 & 0 & 0 & 0 & 0 & $0^{\mathrm{b}}$ \\
\hline $\mathrm{H}^{\prime}$ & 2.43 & 2.63 & 2.23 & 3.28 & 3.20 & 3.31 & $2.85 \pm 0.47^{\mathrm{a}}$ & 2.43 & 1.55 & 2.02 & 1.548 & 1.71 & 3.14 & $2.07 \pm 0.62^{\mathrm{b}}$ \\
\hline $\mathrm{J}$ & 0.61 & 0.71 & 0.71 & 0.84 & 0.80 & 0.81 & $0.75 \pm 0.08^{\mathrm{a}}$ & 0.86 & 0.47 & 0.78 & 0.52 & 0.61 & 0.91 & $0.69 \pm 0.19^{a}$ \\
\hline$\%$-ЕРТ & 0.80 & 36.69 & 4.81 & 1.37 & 14.46 & 3.96 & $10.35 \pm 13.81^{\mathrm{a}}$ & 0.00 & 0.00 & 0.00 & 0.00 & 0.00 & 0.00 & $0.00^{\mathrm{b}}$ \\
\hline$\%$-Ins & 21.60 & 46.04 & 22.12 & 54.79 & 45.78 & 58.42 & $41.46 \pm 15.96^{\mathrm{a}}$ & 43.55 & 2.78 & 17.39 & 37.65 & 13.95 & 29.17 & $24.08 \pm 15.43^{\circ}$ \\
\hline$\%$-Ins-N-Dip & 20.80 & 45.32 & 22.12 & 54.79 & 45.78 & 58.42 & $41.21 \pm 16.12^{\mathrm{a}}$ & 0.00 & 0.39 & 0.00 & 1.57 & 4.65 & 5.56 & $2.03 \pm 2.48^{\mathrm{b}}$ \\
\hline$\%$-Dip & 0.80 & 0.72 & 0.00 & 0.00 & 0.00 & 0.00 & $0.25 \pm 0.39^{\mathrm{a}}$ & 43.55 & 2.38 & 17.39 & 36.08 & 9.30 & 23.61 & $22.05 \pm 15.70^{b}$ \\
\hline \%-Oligo & 0.80 & 0.72 & 0.00 & 0.00 & 0.00 & 0.00 & $0.25 \pm 0.39^{\mathrm{a}}$ & 6.45 & 4.37 & 4.35 & 3.92 & 2.33 & 34.72 & $9.36 \pm 12.50^{b}$ \\
\hline \multicolumn{15}{|c|}{$\begin{array}{l}\text { Pollution tolerance } \\
\text { Index }\end{array}$} \\
\hline$\%$-To & 1.60 & 0.00 & 3.85 & 27.40 & 24.10 & 13.86 & $11.80 \pm 11.87^{\mathrm{a}}$ & 66.13 & 57.1 & 65.22 & 92.94 & 68.6 & 52.78 & $67.14 \pm 13.99^{b}$ \\
\hline$\%$-Into & 6.40 & 34.53 & 6.73 & 1.37 & 24.10 & 10.89 & $14.00 \pm 12.68^{\mathrm{a}}$ & 0.00 & 0.00 & 0.00 & 0.00 & 0.00 & 0.00 & $0.00^{\mathrm{b}}$ \\
\hline$\%$-Dom & 55.20 & 30.20 & 50.00 & 26.03 & 34.94 & 29.70 & $37.68 \pm 12.01^{\mathrm{a}}$ & 25.81 & 54.4 & 43.48 & 55.29 & 55.81 & 20.83 & $42.60 \pm 15.69^{2}$ \\
\hline FBI & 5.59 & 4.22 & 5.54 & 6.44 & 5.51 & 5.28 & $5.43 \pm 0.71^{\mathrm{a}}$ & 8.10 & 7.13 & 7.61 & 7.82 & 7.35 & 7.24 & $7.54 \pm 0.37^{b}$ \\
\hline FMWP & 77.00 & 57.00 & 44.00 & 81.00 & 74.00 & 92.00 & $70.83 \pm 17.38^{a}$ & 54.00 & 68.00 & 47.00 & 54.00 & 54.00 & 80.00 & $59.52 \pm 12.16^{2}$ \\
\hline ASPT & 4.81 & 4.38 & 4.89 & 5.40 & 4.63 & 5.41 & $4.92 \pm 0.42^{\mathrm{a}}$ & 7.71 & 6.80 & 7.83 & 6.75 & 7.71 & 7.27 & $7.35 \pm 0.48^{b}$ \\
\hline
\end{tabular}

Mann Whitney tests were used to evaluate differences among the two groups of streams (forest streams and urban streams). The values followed by the superscript $(a, b)$ for a given metric indicate that this metric is significantly different between forest and urban streams $(\mathrm{P}<0.01)$.

account for $82.53 \%$ of the total abundance in urban streams. In the forest streams, a total abundance of 625 individuals was registered. The Desmocaridae (17.12\%), Thiaridae (15.36\%), Lymnaeidae (10.24\%) and Atyidae (10.24\%) are the most represented benthic macroinvertebrate families in forest streams. Also, pollution-sensitive taxa are significantly represented with Perlidae (8.64\%), Gyrinidae (7.68\%), and Gomphidae (2.72\%). In addition, Statistical analyses revealed that, metric values such as \%-EPT and \%-Ins-N-Dip, were significantly higher $(\mathrm{P}<$ 0.01) in forested streams than in urban streams (Table 5). Inversely, the \%-Dip and \%-Oligo indices showed significantly lower values $(\mathrm{P}<0.01)$ in forested streams as compared to urban streams.

The Shannon and Weaver diversity index $\left(\mathrm{H}^{\prime}\right)$ revealed a significantly higher diversity $(\mathrm{P}<0.05)$ in forested streams $(2.85 \pm 0.47$ bits/ind. $)$, whereas in urban streams subjected to anthropogenic disturbances, lowest values of diversity in- 
dex were noted ( $2.07 \pm 0.62$ bits/ind) (Table 5). Although indicating, a better distribution of individuals within different taxa in forest $(0.75 \pm 0.08)$ and urban $(0.69 \pm 0.19)$ stations, the Pielou evenness index (J) did not vary significantly $(\mathrm{P}>0.05)$ (Table 5). The \%-Into and FMWP indices measuring sensitivity of taxa to pollution were higher in forest streams than in urban ones. For $\%$-To and FBI, the values recorded in urban streams are significantly high $(\mathrm{P}<0.05)$ than those registered in forested sites (Table 5). In addition, the FBI revealed that forest streams waters are of medium quality with fairly substantial organic pollution $(\mathrm{FBI}=5.43 \pm 0.71)$ whereas waters from urban streams are of very poor quality with severe organic pollution ( $\mathrm{FBI}=7.54 \pm 0.37$ ).

Regarding FFGs, in the forest streams, predators and shredders are the most represented with $38.04 \%$ and $30.02 \%$ of relative abundances respectively (Figure 3 ). The collectors-gatherers and the scrapers represent $16.18 \%$ and $15.40 \%$ of the total abundance respectively. The collectors-filterers are very poorly represented with $0.36 \%$ of individuals. In urban streams, macroinvertebrates are dominated by collectors-gatherers, which constitute $82.15 \%$ of the population. However, we also find collectors-filterers, predators and shredders which respectively account for $12.85 \%, 4.80 \%$ and $0.20 \%$ of macroinvertebrates.

\subsection{Relationship between Benthic Macroinvertebrates Metrics and Physicochemical Water Quality}

The PCA based on the physicochemical variables and the benthic macroinvertebrates metrics showed that the first two axes (F1, F2) account for $67.60 \%$ of the total variance (Figure 4). The distribution of the observations according to the factorial plane 1 - 2 discriminates two groups. The group I is consisted of physicochemical parameters such as nitrites, ammonium, orthophosphates, color, SS, turbidity, $\mathrm{pH}$ and temperature, which are positively and significantly correlated to \%-Dip, \%-Oligo, \%-To, FBI and ASPT. It may be thought that benthic

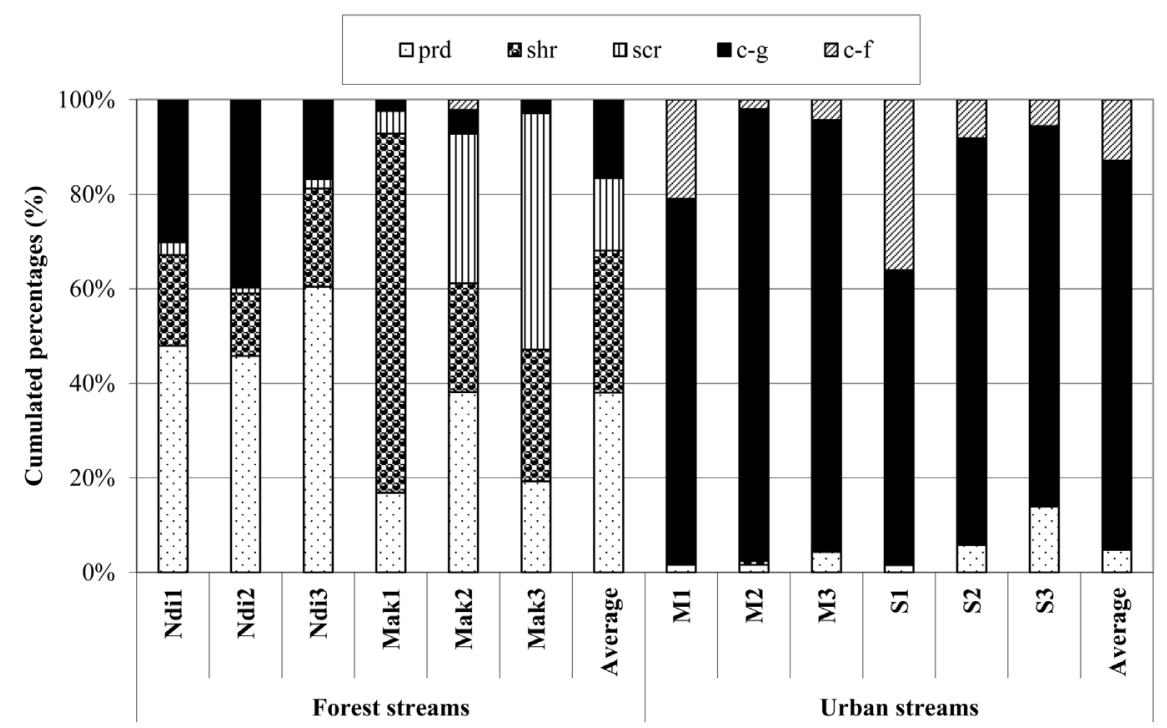

Figure 3. Functional feeding groups identified during study period. 


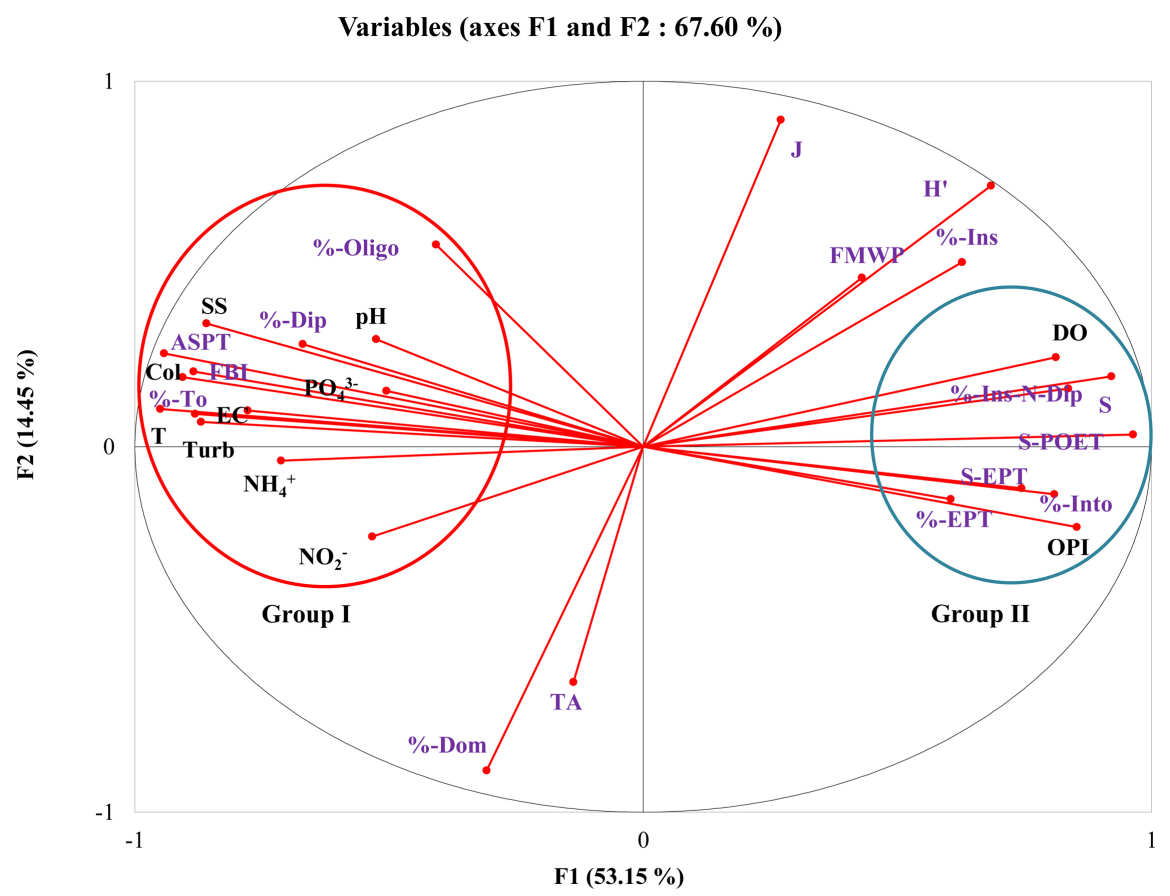

Figure 4. Correlations circle between physicochemical variables and benthic macroinvertebrates metrics from the first two axes (axis 1 horizontal and axis 2 vertical) of the PCA.

macroinvertebrates individuals belonging to the orders of Diptera, Oligochaeta and all other individuals belonging to pollution-tolerant families (tolerance score $>6)$ proliferate in very turbid waters, with high temperature and heavy organic matter load, characteristics of urban streams located in Douala. This is confirmed by the positive and significant correlations between metrics such as \%-Dip, \%-Oligo, \%-To, FBI and ASPT and environmental variables such as temperature, electrical conductivity, color, turbidity, SS, nitrites, ammonium and orthophosphates (Table 6). Inversely, the group II, gathered metrics such as \%-Ins-N-Dip, \%-Into, \%-EPT, S, S-EPT and S-POET which are positively and significantly correlated with dissolved oxygen and OPI (Figure 4), indicating low organic matter load in the forest streams of Yabassi. Similarly, the Spearman correlation matrix revealed that the installation and the proliferation of non-Dipterans insects, EPT, POET and all other sensitive individuals (tolerance score $<4)$ are favored in well oxygenated water with low organic matter concentration (Table 6).

\section{Discussion}

Analysis of environmental variables revealed different water quality profiles for forest and urban sites. In the city of Douala, the combined action of domestic, urban and industrial solid wastes and wastewaters discharged into the streams studied (Mboppi and Simbi) is at the origin of water quality degradation. These wastes mainly come from industries (CCC, SOCARTO, SCIMPOS), unstructured shopping centers (Congo market, Central market, Nkololoun market, 
Table 6. Spearman's correlation coefficient between the physicochemical variables and the benthic macro-invertebrates metrics.

\begin{tabular}{|c|c|c|c|c|c|c|c|c|c|c|c|c|c|}
\hline \multirow{2}{*}{ Variables } & \multicolumn{13}{|c|}{ Metrics } \\
\hline & $S$ & S-EPT & S-POET & $\mathrm{H}^{\prime}$ & $\%$-EPT & $\%$-Ins & $\%$-Ins-N-Dip & \%-Dip & $\%$-Oligo & $\%$-To & $\%$-Into & FBI & ASPT \\
\hline $\mathrm{T}$ & $-0.62^{\star}$ & $-0.85^{\star *}$ & $-0.75^{\star \star}$ & NS & $-0.88^{\star *}$ & $-0.63^{\star}$ & $-0.86^{\star *}$ & $0.75^{\star *}$ & $0.82^{\star *}$ & $0.74^{\star \star}$ & $-0.85^{\star *}$ & $0.79^{* *}$ & $0.82^{* *}$ \\
\hline $\mathrm{pH}$ & NS & $-0.59^{*}$ & NS & NS & NS & NS & NS & NS & NS & $0.69^{*}$ & NS & NS & $0.78^{* *}$ \\
\hline DO & $0.67^{*}$ & $0.82^{\star *}$ & $0.88^{\star *}$ & 0.62 & $0.83^{\star *}$ & NS & $0,83^{* *}$ & $-0.94^{* *}$ & $-0.90^{\star *}$ & $-0.66^{*}$ & $0.80^{* *}$ & $-0.80^{\star *}$ & $-0.69^{*}$ \\
\hline EC & $-0.72^{\star}$ & $-0.78^{\star *}$ & $-0.86^{\star *}$ & NS & $-0.77^{\star *}$ & $-0.61^{\star}$ & $-0.79^{\star *}$ & $0.84^{\star \star}$ & $0.86^{\star *}$ & $0.60^{*}$ & $-0.75^{\star *}$ & $0.67^{*}$ & $0.76^{* *}$ \\
\hline Col & $-0.78^{\star *}$ & $-0.72^{\star}$ & $-0.82^{\star \star}$ & NS & $-0.7^{\star}$ & NS & $-0.73^{\star *}$ & $0.70^{*}$ & $0.73^{\star *}$ & $0.74^{* *}$ & $-0.74^{\star \star}$ & $0.69^{*}$ & $0.77^{\star *}$ \\
\hline SS & NS & $-0.72^{\star}$ & $-0.67^{\star}$ & NS & $-0.7^{\star}$ & NS & $-0.66^{\star}$ & $0.62^{*}$ & $0.72^{\star}$ & $0.72^{*}$ & $-0.70^{*}$ & $0.65^{\star}$ & $0.77^{* *}$ \\
\hline Turb & $-0.73^{\star *}$ & $-0.79^{\star *}$ & $-0.90^{\star *}$ & -0.7 & $-0.78^{\star \star}$ & $-0.74^{\star \star}$ & $-0.78^{\star *}$ & $0.73^{\star *}$ & $0.81^{\star *}$ & $0.61^{*}$ & $-0.78^{\star *}$ & $0.64^{*}$ & $0.74^{* *}$ \\
\hline $\mathrm{NH}_{4}^{+}$ & $-0.76^{* *}$ & $-0.77^{\star *}$ & $-0.88^{\star *}$ & -0.67 & $-0.75^{* *}$ & $-0.65^{\star}$ & $-0.87^{* *}$ & $0.73^{\star *}$ & $0.84^{* *}$ & $0.58^{\star}$ & $-0.75^{\star *}$ & $0.64^{*}$ & $0.78^{* *}$ \\
\hline $\mathrm{NO}_{2}^{-}$ & NS & $-0.81^{\star *}$ & $-0.73^{\star *}$ & NS & $-0.77^{\star *}$ & NS & NS & $0.65^{*}$ & $0.58^{\star}$ & $0.85^{\star *}$ & $-0.77^{\star *}$ & $0.70^{*}$ & $0.76^{* *}$ \\
\hline $\mathrm{PO}_{4}{ }^{3-}$ & NS & NS & NS & NS & NS & NS & NS & NS & NS & NS & NS & NS & NS \\
\hline OPI & $0.48^{\star}$ & $0.86^{* \star}$ & $0.71^{\star}$ & NS & $0.86^{* *}$ & NS & $0.74^{* *}$ & $-0.79^{\star *}$ & $-0.82^{\star \star}$ & $-0.79^{\star *}$ & $0.82^{\star *}$ & $-0.78^{\star *}$ & $-0.78^{\star *}$ \\
\hline
\end{tabular}

Significant correlation $\left({ }^{*}: \mathrm{P}<0.05 ;{ }^{* *}\right.$ : $\left.\mathrm{P}<0.01\right)$; NS: non-significant correlation.

Mboppi market, Sandaga market), households and traditional toilets of the spontaneous habitats. The resulting aerobic degradation of organic matter is responsible of the hypoxic condition of these waters [25]. As regards forest streams, they showed a better water quality due to the presence of riparian vegetation. In fact, the important riparian forest limits the exposure of the streams to solar rays, which considerably reduces the temperature of the water. It also reduces soils erosion and indirectly the amount of nutrients and organic matter loaded in the streams [26]. The values of parameters indicating organic matter load (nitrites, ammonium and phosphates) are lower in forest streams; however, these parameters revealed through the OPI, a moderate organic pollution of water. [27] has attributed such a situation in the forest zone, principally due to the degradation of the litter coming from the riparian vegetation.

Concerning forest streams of Yabassi, there was a numerical preponderance and taxonomic richness of sensitive taxa which includes Decapoda (Atiydae, Desmocarididae) and non-Dipterans Insects (Leptophlebiidae, Baetidae, Potamanthidae, Ephemerellidae, Perlidae, Hydropsychidae, Veliidae, Gomphidae, Gyrinidae, Noteidae, Hydrophilidae, Chrysomelidae). Their preponderance would be related to the good oxygenation of the forest streams. The positive and significant correlations between S-EPT, S-POET, \%-EPT, \%-POET, \%-Ins-N-Dip and the high concentrations of dissolved oxygen in forest streams confirm this observation. This numerical and taxonomic preponderance of Decapoda and non-Dipterans Insects found in the forest streams as compared to their low richness and abundance in the urban streams could reveal a state of advanced degradation of the Mboppi and Simbi stations. [28] showed that taxonomic richness particularly that of aquatic insects can be a good indicator of the influence of anthropogenic disturbances on rivers. Indeed, [16] indicate that aquatic 
insects are highly sensitive to pollution and/or habitat modification, resulting in their disappearance in a disturbed environment. Moreover, the virtual absence of EPT orders in urban stations confirms their great degradation.

In a study conducted in the United States, [29] indicate that EPT taxa are among the most sensitive benthic macroinvertebrates and therefore their species richness decreases drastically with the urbanization of watersheds. Our results are in line with those of [30] who showed that a decrease in the number of EPT taxonomic richness in human impacted streams is clearly related to changes in water quality and habitat suitability. For freshwater Decapoda, it is recognized that these organisms proliferate in well-oxygenated waters [16] [31]. In addition, the great prominence of the Decapoda order would also be related to their belonging to the functional feeding groups of shredders and to the presence of large amounts of litter in forest streams. They find an important part of their food resources in the litter. [32] showed that macroinvertebrates associated with litter in Guinea's rivers were largely dominated by shredder Decapoda.

The proliferation of Physidae, Lymnaeidae and Chironomidae in the urban streams of the city of Douala is explained by the fact that these waters systems are subjected to heavy organic matter load. To live in such disturbed environments, these organisms have developed special adaptations. Indeed, [33] showed that Physidae and Lymnaeidae have a rudimentary lung through which they breathe atmospheric air and thus can live in hypoxic aquatic environments. Moreover, their rapid maturation and their ability to self-fertilize in difficult conditions are also at the origin of their important development [34]. As for Chironomidae, studies by [35] [36] have shown that these organisms have adapted to hypoxic media with the hemoglobin in their hemolymph which allows them to store oxygen in the cuticle when it is abundant in the medium and to release it when its concentration becomes low. Furthermore, Chironomidae have what appears to be finger-like "gills" at the posterior ends of their bodies, which are actually involved in osmoregulation and permitted them to live in polluted waters with high ionic concentrations [8]. In addition, the high abundance of Physisae, Lymnaeidae and Chironomidae is related to their feeding mode; indeed, they are collectors-gatherers and proliferate in turbid aquatic milieu with important decaying organic matters load [24]. This is primarily due to various anthropogenic pollution sources found in the rivers basins of Douala township.

\section{Conclusion}

In this study, the set of benthic macroinvertebrates metrics and FFGs used to describe the health status of the watersheds reveals very poor water quality and poor diversity of benthic macroinvertebrates in urban streams. On the other hand, these metrics and FFGs have highlighted better water quality and high biodiversity in Yabassi forest streams. The benthic macroinvertebrates communities encountered in the studied streams showed different sensitivities to en- 
vironmental conditions, confirming the reliability of benthic macroinvertebrates in assessing disturbances in streams of the coastal ecological region of Cameroon.

\section{Conflicts of Interest}

The authors declare no conflicts of interest regarding the publication of this paper.

\section{References}

[1] Wang, B.D., Liu, S., Liu, Y., Zhang, D., Lu and Wang, L. (2012) Impacts of Urbanization on Stream Habitats and Macroinvertebrate Communities in the Tributaries of Qiangtang River, China. Hydrobiologia, 680, 39-51. https://doi.org/10.1007/s10750-011-0899-6

[2] Barbour, M.T., Gerritsen, J., Snyder, B.D. and Stribling, J.B. (1999) Rapid Bioassessment Protocols for Use in Stream and Wadeable Rivers: Periphyton, Benthic Macroinvertebrates and Fish. 2nd Edition, U.S. Environmental Protection Agency, Office of Water, Washington DC.

[3] Gresens, S.E., Belt, K.T., Tang, J.A., Gwinn, D.C. and Banks, P.A. (2007) Temporal and Spatial Responses of Chironomidae (Diptera) and Other Benthic Invertebrates to Urban Stormwater Runoff. Hydrobiologia, 575, 173-190.

https://doi.org/10.1007/s10750-006-0366-y

[4] Foto Menbohan, S., Koji, E., Ajeagah Gideon, A., Bilong Bilong, C.F. and Njiné, T. (2012) Impact of Dam Construction on the Diversity of Benthic Macroinvertebrates Community in a Periurban Stream in Cameroon. International Journal of Biosciences, 11, 137-145.

[5] Foto Menbohan, S., Tchakonte, S., Ajeagah, G., Zebaze Togouet, S.H., Bilong Bilong, C.F. and Njine, T. (2013) Water Quality Assessment Using Benthic Macroinvertebrates in a Periurban Stream (Cameroon). International Journal of Biotechnology, 2, 91-104.

[6] Nyamsi Tchatcho, N.L., Foto Menbohan, S., Zebaze Togouet, S.H., Onana, F.M., Adandedjan, D., Tchakonte, S., Yemele Tsago, C., Koji, E. and Njine, T. (2014) Multimetric Index of Yaounde Benthic Macroinvertebrates (IMMY) for the Biological Assessment of Stream Water Quality in the South-Central Forestry Region of Cameroon. European Journal of Scientific Research, 123, 412-430.

[7] Tchakonté, S., Ajeagah, G.A., Diomande, D., Camara, I.A. and Ngassam, P. (2014) Diversity, Dynamic and Ecology of Freshwater Snails Related to Environmental Factors in Urban and Suburban Streams in Douala-Cameroon (Central Africa). Aquatic Ecology, 48, 379-395. https://doi.org/10.1007/s10452-014-9491-2

[8] Tchakonté, S., Ajeagah, G.A., Camara, A.I., Diomandé, D., Nyamsi Tchatcho, N.L. and Ngassam, P. (2015) Impact of Urbanization on Aquatic Insect Assemblages in the Coastal Zone of Cameroon: The Use of Biotraits and Indicator Taxa to Assess Environmental Pollution. Hydrobiologia, 755, 123-144. https://doi.org/10.1007/s10750-015-2221-5

[9] Onana, F.M., Zébazé Togouet, S.H., Koji, E., Nyamsi Tchatcho, N.L. and Tchakonté, S. (2016) Influence of Municipal and Industrial Pollution on the Diversity and the Structure of Benthic Macro-Invertebrates Community of an Urban River in Douala, Cameroon. Journal of Biodiversity and Environmental Sciences, 8, 120-133.

[10] Wasson, J.G. (1989) Main Typological Approaches for Running Waters: A Critical 
Review. Bulletin d Ecologie, 20, 109-127.

[11] Suchel, J. (1972) Climates of Cameroon. PhD Thesis, Universityof Bordeaux III, Bordeaux.

[12] Rodier, J., Legube, B. and Merlet, N. (2009) The Water Analysis. 9th Edition, Dunod, Paris.

[13] Leclercq, L. and Maquet, B. (1987) Two New Chemical and Diatomic Indices of Running Water Quality. Application to Samson and Its Tributaries (Belgian Meuse Basin). Comparison with Other Chemical, Biocenotic and Diatomic Indices. Royal Institute of Natural Sciences of Belgium, Bruxelles, Work Document 38, 1-113.

[14] Stark, J.D., Boothroyd, K.G., Harding, J.S., Maxted, J.R. and Scarsbrook, M.R. (2001) Protocols for Sampling Macroinvertebrates in Wadeable Streams. New Zealand Macroinvertebrates Working Group, Report No. 1, Ministry for the Environment Report, 1-57.

[15] De Moor, I.J., Day, J.A. and De Moor, F.C. (2003) Guides to the Freshwater Invertebrates of Southern Africa, Volume 7: Insecta I. Ephemeroptera, Odonata, Plecoptera. Prepared for the Water Research Commission, Pretoria, WRC Report No. TT 207/03, Pretoria.

[16] Tachet, H., Richoux, P., Bournaud, M. and Usseglio-Polatera, P. (2006) Freshwater Invertebrates: Systematic, Biology and Ecology. CNRS Editions, Paris.

[17] Tachet, H., Richoux, P., Bournaud, M. and Usseglio-Polatera, P. (2010) Freshwater Invertebrates: Systematic, Biology and Ecology. CNRS Editions, Paris.

[18] Camargo, J.A., Alonso, A. and De la Puente, M. (2004) Multimetric Assessment of Nutrient Enrichment in Impounded Rivers Based on Benthic Macroinvertebrates. Environmental Monitoring and Assessment, 96, 233-249. https://doi.org/10.1023/B:EMAS.0000031730.78630.75

[19] Dajoz, R. (2000) Fundamentals of Ecology. Dunod, Paris.

[20] Li, L., Zheng, B.H. and Liu, L.S. (2010) Biomonitoring and Bioindicators Used for River Ecosystems: Definitions, Approaches and Trends. Procedia Environmental Sciences, 2, 1510-1524. https://doi.org/10.1016/j.proenv.2010.10.164

[21] Tolkamp, H.H. (1985) Biological Assessment of Water Quality in Running Water Using Macroinvertebrates: A Case Study for Limburg, the Netherlands. Water Science and Technology, 17, 867-878. https://doi.org/10.2166/wst.1985.0186

[22] Bode, R.W., Novak, M.A., Abele, L.E., Heitzman, D.L. and Smith, A.J. (2002) Quality Assurance Work Plan for Biological Stream Monitoring in New York State, Albany (New York). Stream Biomonitoring Unit Bureau of Water Assessment and Management, Division of Water. NYS Department of Environmental Conservation.

[23] Hilsenhoff, W.L. (1988) Rapid Field Assessment of Organic Pollution with a Family-Level Biotic Index. Journal of the North America Benthological Society, 7, 65-68. https://doi.org/10.2307/1467832

[24] Cummins, K.W, Merritt, R.W. and Andrade, P.C.N. (2005) The Use of Invertebrate Functional Groups to Characterize Ecosystem Attributes in Selected Streams and Rivers in South Brazil. Studies on Neotropical Fauna and Environment, 40, 69-89. https://doi.org/10.1080/01650520400025720

[25] Othoniel, C. (2006) The Growth of Photosynthetic Biofilm: An Indicator of the Trophic Status of Rivers? PhD Thesis, University of Bordeaux I, Bordeaux.

[26] Allan, J.D. and Castillo, M.M. (2007) Stream Ecology: Structure and Function of Running Waters. 2nd Edition, Springer, Dordrecht.

[27] Lecerf, A. (2005) Anthropogenic Disturbances and Ecological Functioning of 
Headwater Streams: Study of the Litter Decomposition Process. PhD Thesis, University of Toulouse III, Toulouse.

[28] Wang, S.Y., Bernhardt, E.S. and Wrigh, J.P. (2014) Urban Stream Denitrifier Communities Are Linked to Lower Functional Resistance to Multiple Stressors Associated with Urbanization. Hydrobiologia, 726, 13-23.

https://doi.org/10.1007/s10750-013-1747-7

[29] Carliste, D.M., Meador, M.R., Moulton II, S.R. and Ruhl, P.M. (2007) Estimation and Application of Indicator Values for Common Macro-Invertebrates Genera and Families of the United States. Ecological Indicators, 7, 22-23. https://doi.org/10.1016/j.ecolind.2005.09.005

[30] Song, M.Y., Leprieur, F., Thomas, A., Lek-Ang, S., Chon, T.S. and Lek, S. (2009) Impact of Agricultural Land Use on Aquatic Insect Assemblages in the Garonne River Catchment (SW France). Aquatic Ecology, 43, 999-1009. https://doi.org/10.1007/s10452-008-9218-3

[31] Fossati, O., Mosseron, M. and Keith, P. (2002) Distribution and Habitat Utilization in Two Atyid Shrimps (Crustacea: Decapoda) Macro- and Micro- in the Rivers of Nuku-Hiva Island (French Polynesia). Hydrobiologia, 472, 197-206. https://doi.org/10.1023/A:1016311220269

[32] Tenkiano Doumbou, N.S. (2017) Benthic Macroinvertebrates and Aquatic Hyphomycetes: Diversity and Involvement in the Ecosystem Functioning of Guinea's Watercourses. PhD Thesis, University of Toulouse, Toulouse.

[33] Mouthon, J. (2001) Freshwater Mollusks and Biodegradable Pollution of Rivers: Proposal of Scale of Species Sensitivity, Genera and Families. Ingénieries, 26, 3-15.

[34] Dillon, R.T.Jr., McCullogh, T.E. and Earnhardt, C.E. (2005) Estimates of Natural Allosperm Storage Capacity and Self-Fertilisation Rate in the Hermaphrodite Freshwater Pulmonate Snail, Physa acuta. Invertebrate Reproduction and Development, 47, 111-115. https://doi.org/10.1080/07924259.2005.9652151

[35] Scholz, F. and Zerbst-Boroffka, I. (1998) Environmental Hypoxia Affects Osmotic and Ionic Regulation in Freshwater Midge-Larvae. Journal of Insect Physiology, 44, 427-436. https://doi.org/10.1016/S0022-1910(98)00031-6

[36] Merrit, R.W., Cumins, K.W. and Berg, M.B. (2008). An Introduction to the Aquatic Insects of North America. Fourth Edition, Kendall/Hunt Publishing Company, Iowa. 